\title{
Venture Capital Fund-a Partner of Development of SMES and It Firms for an Economically Developed Digital Bangladesh
}

\author{
Shahanaz Akter, Dr. Mohammad Jahangir Alam \\ Lecturer, Department of Finance and Banking, Faculty of Business Studies \\ Jashore University of science and Technology, Jashore- 7408 \\ Chairman, Department of Finance and Banking, Faculty of Business Studies \\ Jashore University of science and Technology, Jashore- 7408
}

\begin{abstract}
For the development of any country, the development economy is crucial and for the development of economy nourishment and proper burgeon of the business must be ensured. Bangladesh has recently stepped up to the "Developing" ranking and aiming for sustainable development. Entrepreneurship had been the most important contributor in economic development in terms of employment, innovations and healthy market competition over the last decades. As such, Entrepreneurship is the primary factor in the development of economies. A new business always affects the people and the economy of the locality as anew opportunity gets created for employment, earnings and better living standard. Eve depending on one business in a local area may engender other related business. For example, an opening of a new branch of the bank may inspire the entrepreneurs of that area to implement their business plans. The Theory of Kirzner (1973-2005) about entrepreneurship explains how the improvement of economic health affects individuals in the first world. It is needless to say, how the development of services such as roads, public transportations, health, education, and entertainment are backed by the growth of industries and companies in various fields. The implementation of those industrial activities resulted in the development of a more vibrant economy.

As such, for an economy to operate smoothly and to be in a good state, it highly depends on the Financial Institutions which assists to keep economy hydrated. Hence, a regular and even flow of fund encourages business development or entrepreneurship and operations which ensure economic growth. In Bangladesh, there are Banks and Non-Banking Financial Institutions for this very purpose. But there come some limitations under the decision-making system of these institutions when the subject customer is new entrepreneurship or developing or Greenfield Company, which has high growth potential as well as high risk of default. Therefore, there is still a gap between the required fund for any new business and actual funds that can be disbursed from Banks and NBFIs.

Venture Capital is a category of equity or debt finance or combination of both which is generally offered to entrepreneurs and small companies, which bear high growth potential but also prone to high risk. Venture capital funds differ from the other investment companies as the others try to limit their risk-taking actions up to a specified ceiling with specified rules and guidelines made by the company articles of association and memorandum of association and management principles governed by the board.

As venture capital firms invest in highly risky firms, they use the risk diversification approach. That means, they usually make small investments on a variety of young startups, as they trust about at least one firm's high growth and business success which will set off with comparatively large payout at the end. This mechanism obviously diverts the risk of other small investments' failure.

Even though Venture Capital is a still-developing concept in Bangladesh as a vital source of funds and assistance, it is already a popular way of business development for developed countries. This paper is aimed to discuss the prospect of Venture Capital in Bangladesh and how this financing assists as coentrepreneur of start-ups and growing ventures.
\end{abstract}




\section{Introduction}

By definition, Venture Capital is a type of private equity financing or debt financing or hybrid financing arrangement \& other supports supplied to the startups or growing companies that have a lack of financing to start or grow the venture. Generally, a start-up firm goes through several stages like- Pre-seed stage, seed stage, first stage, second stage, third stage, later-stage financing. As such, needing companies may need different financing at different stages. However, a small firm may face different kinds of challenges, in them, a financial crisis may become a big obstacle to start or grow. The present financial industry norm, situation, and principles of providing loan inherit many restrictions and formal barriers which do not let a risky project financing in an easy way, sometimes the financing becomes impossible. Generally, the traditional baking and non-banking financial institutions look for business experience, collateral, personal guarantees, personal net worth, family background, creditworthiness, etc. On the other hand, the process of raising equity funds from the stock market of Bangladesh is quite difficult and needs to be meeting up the constraints and requirements of a listing. As such, many new or novice entrepreneurs with prospective ideas cannot mitigate both short term and long term financial limitations if they seek financing from these traditional financial institutions. Venture Capital, a far more supportive financing option can be $\mathrm{n}$ angel to solve this issue. Not only financial assistance but also the advisory service also buttress the new firms and ventures. This customary service helps tremendously for developing SMEs, new entrepreneurship. Thus, the Venture Capital concept is new but very promising for the development of the Bangladesh Economy.

\section{What is Venture Capital}

A venture capitalist firm is a company which supplies capital to the new ventures, provides legal \& management advisory services, networking \& marketing support to raise up the innovative ideas up to the final stage of development and other bridging support. A venture capital firm not only finances early-stage companies but also in the growth phase of the company with equity financing/debt financing or both combining other technical and managerial supports and VCs take high risk expecting that a few of the firms they support will become successful. Since the startups face high uncertainty, Venture Capital investments have high rates of failure. The start-ups may be structured on the basis of an innovative technology/ business model/high technology industries, such as IT, clean technology/ biotechnology.

\section{Registration \& regulations of Venture Capital Funds in Bangladesh}

In Bangladesh, the VCs are primarily registered with the Register of Joint Stock Companies (RJSC) as limited share companies under the Companies Act 1994. The companies also must be structured and operate under Bangladesh Securities \& Exchange Commission (BSEC) rule, which is in force since $22^{\text {nd }}$ June 2015. Until January 2018, around 11 companies got registration from BSEC. Under these rules, three types of funds got registration- 'Private Equity Fund', 'Venture Capital Fund' \& 'Impact Fund'. But, among 11 of them, only a few started its operations in actual. However, Venture Capital fund means the firm which is an alternative investment fund,that invests basically in unlisted securities of new ventures which have the record of fewer than 2 years of operation/greenfield firms/new highly prospective \& innovative ideas, products, services, technologies, business models. There are few restrictions in investors that provide capital to the fund as well as in investments from the fund as well under the rule. But the latest rule of BEC (2016) is better to the former rules (2015) in terms of an easier exit of the venture capital firm from the industry. As such, less restriction instigates newer firms to come forward in the industry. The new rule allows small firms with low capital (less than 300 million) to be enlisted in the Capital market through IPO. Understanding the significance of the contribution of the venture capital fund in the development of the economy of Bangladesh, Bangladesh Bank, the Central Bank of Bangladesh has allowed every commercial Bank to invest two billion taka in new ventures as venture capital fund. This has spread the scope of the fund 
utilization of commercial banks and also allowed them to take more risks beyond their usual principle regarding risk-taking.

\section{Source of fund and investment of Fund by VC}

Generally, a venture capital fund is raised from public investors through IPO or Private investors in the form of equity or semi-equity capital. Then this fund is invested in new ventures in the form of common shares/preferred shares (convertible/inconvertible)/debentures and the tenure of the fund is long term. Mainly the huge amount of capital gain is the main objective of the venture capital financing by providing proper management support by the venture capital firms. They are not the only financer for a company, but they are also the owner of the company for a specific time period.

There are different phases of a firm's growth up to mature stages which may require venture capital funding and the availability, rates, financial and the relevant assistance varies across the stages. The following are the stages of a firm's growth:

i. Pre-seed stage/Idea Generation: In this stage, the entrepreneurs try to make the initial development of the product and create a minimum viable product. As such, some funds are required for idea development and construction of a demo of the product, marketing and sales. Like, idea development, feasibility assessment of the product, industry analysis, prospect measurements, etc.

ii. Start-up: Fresh start-up firms require proper funding for marketing and new product development which is provided in this phase by the venture capital fund.

iii. First-Round: In this phase, the VC supports with the money required for manufacturing and early sales and network establishments.

iv. Second-Round: In this phase, an operational capital provided mainly for early-stage companies that have started selling its product recently, but for achieving the profit margin,they need more production for selling more and surpassing the break-even point.

v. Third-Round: It is called also as Mezzanine financing, which is the financing for the purpose of expansion of the newly established firm.

vi. Fourth-Round: This round is also known as bridge financing, which is proposed for financing the "going public" process.

\section{Process of Venture Capital Financing}

i. Deal Origination: In this phase, the Venture Capitalists are contacted by the entrepreneur for financing their need for business startups and development. In this phase, the entrepreneur provides available documents and business plans.

ii. Screening: This is a preliminary screening phase. In this phase Venture, capitalists gather all the information for the assessment of projects' prospects, available technology, and feasibility in the market, size of the investment, geographical area and present stage of the project. Most often, for clarification of the business plan and market position the customer is called and discussed face to face.

iii. Evaluation: In this phase, the venture capitalists look into the project in detail. Like project profile, the previous track record of the founders, market prospect, profitability, future sales, technical feasibility etc. Hence, the customer's integrity, long term vision, managerial skills, business orientation, technical competence, experience and project's viability is examined in detail. All other risks are also considered carefully in this phase.

iv. Deal Negotiation: When the venture is viable according to the analysis, venture capitalists negotiate the deal with the entrepreneurs. The deal contains certain protective covenants such as venture capitalists have the right to regulate the venture company and to change its management, if 
necessary, buy-back arrangements, acquisition, making IPOs. Conditions of the deal should be mutually advantageous to both parties - venture capitalist and the entrepreneur. It should be tractable and its arrangement should protect the interests of both the parties.

v. Post Investment Activity: In this phase, the Venture starts operation and the Venture capitalist takes part in the management of the Venture and tries to regulate according to the conditions set in the deal. Generally, a representative is appointed from the Venture Capital firm who takes the seat on the board of the new venture and strives for improvement of marketing, finance and managerial functions whenever the crisis occurs.

vi. Exit Plan: In this stage, the Venture Capital firm tries to exit with the expected gain/minimum loss from the firm it invested. The venture capital firm must plan the time \& mode of exit and this depends on the nature of the firm, state of competition \& market situation.

\section{Advantages and Disadvantages of Venture Capital Financing}

There are some pros and cons for venture capital financing which are discussed below:

Advantage of VC financing: As an advantage, the Venture Capital brings wealth and expertise to the company, a big amount of equity finance can be provided. Moreover, the VCs are managing partners of the company and they do not impose any obligations to repay the money on the new firms. Not only capital but also VCs provide vital information, expertise and technical support to make a new venture successful.

Disadvantage of VC financing: On the contrary, the entrepreneur himself loses control; autonomy and freedom as the VC firm become the part-owner of the company/firm. Moreover, venture capital financing is risky for an entrepreneur because the unique idea gets exposed to a third party. As such, there is a threat of idea theft if the venture capital firm ultimately does not make a deal with the founder of the company. In addition to that, the venture capital financing is a lengthy, complex process and also an uncertain form of financing. To the venture capital firm, it is also a risky, lengthy process and requires double management efforts beyond own venture capital firm. Ultimately, the benefit from such financing can be realized in the long run only.

\section{Present Condition of VCs in Bangladesh}

Venture Capital financing assists technically good and potential projects to compete in the global market by preparing them with quality and value efficiency. In Bangladesh, VC funds are still a brand new financing concept to be developed. But, the cause behind the recent growth of South Asian Economies like Singapore, Republic of Korea, Malaysia and India is that the huge stock of venture funds raised from home and abroad. In Bangladesh, though several VC funds are registered with the RJSC and BSEC, some of them are operational. However, Bangladesh's economy with opportunities for young entrepreneurs and development and patron of the latest ideas and corporations are very crucial for the sustainable economic process of Bangladesh. But as the VC concept and funds are new, their performance can't be measured at this moment in numeric terms. Some firms of VC are yet to induce registered with BSEC but they need already invested some funds in new ventures and got success (for example; Popular Pharma by Brummer \& Partners Asset Management. Among the registered VC companies, BD Venture Limited has signed a MoU with US-based DEFTA Partners to finance the business ventures mutually. The VC capital firms offer seed capital to the firm to develop new ideas and ventures. Venture Investment Partners Bangladesh Limited (VIPB) is one of the registered risk capital which provides seed financing similarly as promotes mainly the SMEs. Around 500 small SMEs in the rural areas are financed VIPB in keeping with them. If some more success stories are added to the current trend, hopefully, more and more venture capital firms will step up to buttress the entrepreneurs of SME, IT industries \& innovations inthis country.

\section{Factor considered before Venture Capital Investments}


i. Capital Gain Perspective: A venture capitalists always seek for a capital gain of approximately 30$40 \%$ from a potential venture.

ii. Stage of Investment: If a venture capital fund is invested in a firm at its early stage, the more risk is assumed by a venture capitalist. As such, the earlier the investment stage, the riskier is the investment and hence, more return is required by a venture capitalist.

iii. Proper financial requirement estimation and business projection: A venture capitalist firm has to depend at least on the close to exact/approximate and reliable amount of business requirement based on present business condition and realistic projection of future business, scope, nature, and performance of the new venture.

iv. Management: Often it adds extra cushion for a venture capital fund's investment when it finds a united, experienced, aggressive, pro-active, mature and efficient management team on the board.

v. Owners' Equity: Though venture capital firms don't rely solely on equity of the founders and cofounders of the company and their asset base for investment consideration, this feature mitigates a venture capitalists' dilemma of putting a bet on a new and fresh start-up.

\section{Venture Capital Funds' importance in Bangladeshi Economic Growth through SME financing\& Nourishment of IT sectors}

Both in the developing countries as well as in the developed countries, SMEs are becoming a matter of high attention. SMEs are the main stimulators of economic development in market economies. Until most recently, the private segments of many rising economies were feeling the loss of the center degree of improvement. Financial specialists, policymakers, and experts devoted the vast majority of their endeavors to enormous organizations of more than 500 representatives, bigger undertakings or multinationals. Big Enterprises and MNCs are actually the main targets of TAX provisions and appropriations through associations like World Bank and UNDP were pinpointed the assistance to the smaller scale endeavors which for the most part have less than 5 workers. Between these two limits, lie the SME organizations. SMEs assume a major job in the vitalization and advancement of national economies since they are making openings for work, advances soundness and improvement of local economies, deliver a significant part of the inventiveness and development that powers financial advancement, advance the challenge and collaboration and produce high worth included items. Previously, SMEs have been considered as not being the key component to drive the economy subsequently it was considered as not qualified to center the approaches of the administration to them. Be that as it may, recently there have been many promising activities to help the SMEs working in vital sections of rising economies by ventures as well as business pioneers also, pioneers who unmistakably perceive the job of SMEs in building an economical economy improvement.

In Bangladesh, perhaps SME is the biggest area that is very prospective for its high growth potentiality. In this sector, there is a visible gap in financing needs and actual financing offered by financing companies. Moreover, SMEs also need these support as well - idea development, standard product development, communication \& network buildups, pilot marketing, broad industry inspection, marketing strategy set up, technical support, managerial efficiency, cost management, operational strategy buildup etc.

In Bangladesh, any Entrepreneur looks for financing from Banks and NBFIs as the primary source of Financing. But, Banks and NBFIs always take less risk to save the depositors' money and restrict their own scope of financing though they foresee high returns. Also, they focus on the basic fundamentals and follow the checklist to follow in sanctioning any loan:

- The asset of the company

- Personal Net Worth of the entrepreneur 
- Previous business experience

- Previous credit history (CIB report)

- Customer Background (Family history and business)

- Creditworthiness

- Records of previous industry success of the new idea of business

- Rigid policy made by management to the sector to invest etc.

- Other complete documentation

- Collaterals

Moreover, whatever the condition and progress the new company/ venture achieves, Banks and NBFIs make sure about their timely repayments of interest and the principles as well. As such, as a new firm formed so recently, needs time to grow up and take place in the market, any new venture owner will not prefer to take loans from these kinds of organizations.

But, Venture Capital Fund's rules and regulations are far less constricted compared to Banks and NBFIs in case of funding new ventures and SMEs. Though Bangladesh Bank has declared many facilities and provisions to Banks for venture capital funding to new start-ups, Banks, and NBFIs do not feel liberal to bet on risky ventures. There are lists of supports needed by a new startup, among them, financial support (credit/equity financing), advisory support, management expertise, legal support, regulatory support, marketing support etc. Unlike traditional financing supports (credits) offered by Banks and NBFIs, the Venture Capitalists hold up t $49 \%$ equity in a venture and nurture a new venture which needs to grow up in the market. As such, from seed financing to the marketing advisory services, venture capital firms take seats in the board with versatile expertise to push the new firm to the ultimate success. So, the main difference between the venture capital fund and general financing companies is the ownership or equity holding of the company and taking part in the management of the company.

As such the "Participatory management approach" of venture capital fund management teams reduces these obstacles for the development of enterprises and entrepreneurs. Banks are the traditional lender and the venture capitalists are partners of the growing company. On the contrary, Banks always feels hesitant to take such high risk and mostly gets discouraged for financing an SME enterprise. Not only seed financing but also intermediate financing are also fear for Banks in the case of SMEs. Though Giant Corporation may show high numerical sales figures showing big business prospects and Banks see them the lucrative options of investment. But, here if the Banks consider the percentage of risk to the return, certainly SMEs will how a better number to work with. But, in Bangladesh, the culture is not developed enough to see the real scenario of risk/return profile of the company rather the fame and the asset/sales figures are quite a big issue to consider for a prospective financing client for NBFI/Banks. In such a case, Venture Capital firms are life saviors of SMEs. But the Venture Capital Firms are facing hardship to arrange to finance for their own business startups as the investors are not interested in this new concept of financing and there are a few success stories of venture capitals in hand as Venture Capital Financing is a developing concept. In this case, as Banks are quite privileged having provision from BB to investment in this area, this sector can grow to build up SMEs. Though policymakers and regulators of the financial market understand that a Venture Capital must take a lot more risks than the traditional financial institutions, they have also imposed certain rules, guidelines, stringent regulatory and reporting requirements to save the investors and the venture capital firms themselves. A healthy balance between them is too important for the development of the Venture Capital Industry in Bangladesh.

Bangladesh is continuously growing its Information and communication sector to make a Digital Bangladesh. As such, there are sales opportunities for IT startups, innovative technologies etc. The Government has undertaken a pioneering initiative titled Innovation, Design \& Entrepreneurship Academy that is iDEA under the revolutionary Startup Bangladesh Initiative". The aim is to create a national entrepreneurship platform to enable Bangladesh to innovate faster, create new opportunities, develop 
technical skills, and help realize the vision of Digital Bangladesh. As Bangladesh is becoming more and more involved with the whole world in terms of Business, Transactions, and Education etc. As such, only research and innovation can make our country to step forward to keep the pace of globalization and in the future, we can expect to compete with the other developed countries of the world. Venture capital supports innovations and ICT division of Bangladesh expecting young entrepreneurs to come forward to develop the IT sector of the country. As such, more active supports of several VC funds will ameliorate the IT sector growth and development and will make the dream come true of a Digital Bangladesh.

\section{Challenges faced by Venture Capital Funds in Bangladesh:}

i. In Bangladesh, there may be a lot of prospective ventures to invest for VCs but they cannot provide proper documentation of financial records. As such, as a financing company at least they must not bet blindly. Investment readiness is quite important.

ii. Many ventures are promising but as they are in the embryonic stage many VCs still prefer to invest in the time of growth, not in seed-stage or startups.

iii. There are not developed markets for other equity/debt options like convertible securities in Bangladesh.

iv. Venture Capital firms themselves face the crisis of funds to make their own startups as the VC funding concept is still new for Bangladesh.

v. Many of the entrepreneurs do not know the information of Venture Capital firms and they often left in the dark with their prospective business ideas.

vi. The investments long term time horizon to payback. As such, it becomes difficult to keep the investment freeze in such a long period as the venture capital firm must run its own firm to operate smoothly.

vii. A very promising but immature market for a unique product or service often does not offer enough information to forecast market prospects, profitability and viability of the product/service in their embryonic stage.

viii. Regulatory authorities and institutions in Bangladesh possess many dishonest officers who lag the process of licensing and other motivating facilities offered for entrepreneurs to grow up to the finance application stage. As such, many entrepreneurs do not step forward to the next level daunting these hassles.

11. Conclusion:The trend of Venture capital financing is growing up day by day. There are many big companies are started up by the financing of venture capitals in developed countries; such as Snapchat, Xiaomi, Uber, and SpaceX etc. In a recent trend, most software companies, bio-technology \& entertainment sectors are mostly getting financed by venture capital funds allover the world. In Bangladesh, SMEs, IT sectors, other software and networking technology-oriented firms are getting prioritized for venture capital financing. Now, it is the time of globalization. Companies and firms have to be competitively advance in terms of cost, differentiation, quality and unique customer group focus. Bangladesh's government is trying very hard to develop SME as well as the IT sector and to promote innovations in Bangladesh. If once the venture capital industry gets developed this financing industry will further develop the economy of the developing country like Bangladesh.

\section{Reference:}

[1] Brealey Richard A., \& Myers StewartC.(2000). 'Principles of Corporate Finance', Tata McGrow Hill, New Delhi.

[2] Rutagi RP (2001) 'Financial Management Theory, concept and Problem', Galgotia Publishing Company, New Delhi. 
[3] The Role Of Entrepreneurship In Economic Development,The Startup Magazine. (2017, August 23). Retrieved from http://thestartupmag.com/essay-on-role-entrepreneurship-economicdevelopment/.

[4] R.Swathi (2018), 'Venture CapitalFunding- Recent Trends and Challenges in India', UGC Journal No. 45308, India.

[5] Shah Md Ahsan Habib, (2008, April 04). Venture capital: Bangladesh perspective. The Financial Express. Retrieved fromhttps://thefinancialexpress.com.bd/views/venture-capital-bangladeshperspective-1523197842.

[6] Masihul Huq Chowdhury,(2017, July 6). Venture capital for the future growth of Bangladesh. The Independent. Retrieved fromhttp://www.theindependentbd.com/post/102523.

[7] The State and Future Of Venture Capital In Bangladesh With Shawkat Hossain, Managing Director, BD Venture Limited: Future Startup, (2018 June 6). Retrieved from https://futurestartup.com/2018/06/06/the-future-of-venture-capital-in-bangladesh-with-shawkathossain/

[8] Process of Venture Capital Financing: 6 Main Steps, Suraj B Gupta, (Undated). Retrieved from http://www.yourarticlelibrary.com/financial-management/venture-capital/process-of-venturecapital-financing-6-main-steps/72037.

[9] Alternative Funds 2019, Syed Afzal Hasan Uddin and Imtiaz Bin Hafiz, ( 2019, September 5). Retrieved from https://practiceguides.chambers.com/practice-guides/alternative-funds2019/bangladesh

[10] Venture Capital, EduPristine,(2017, December 7). Retrieved from https://www.edupristine.com/blog/venture-capital.

[11] Role of SMEs in Economic Development, UKESSAYS, (2017, July 14). Retrieved from https://www.ukessays.com/essays/economics/smes-role-in-national-economies-economicsessay.php 